\title{
Studi Komunikasi Ritual Teh Pai Pada Pernikahan Tionghoa Cina Benteng di Tangerang
}

\author{
Putri Dewiyanto, Suzy S. Azeharie \\ putridewiyanto@gmail.com, Azehariesuzy@yahoo.com \\ Fakultas Ilmu Komunikasi Universitas Tarumanagara
}

\begin{abstract}
China Benteng is a famous community because it is still considered to preserve Chinese cultural traditions. One of the cultures is Pai Tea. Pai tea is inherited through a process of communication between generations. In Pai Tea rituals there is a communication process that involves the deepest feelings between brides and older people. The deepest feeling is part of ritual communication. The purpose of this study was to determine the communication of Pai Tea rituals at Chinese Benteng Chinese marriages in Tangerang. The theory used in this study is the theory of communication, ritual communication and culture. The research method used is descriptive phenomenological qualitative research method. The data to be analyzed is obtained from the results of in-depth interviews with five speakers. The conclusion of this study is that the communication of rituals contained in Pai Tea on Chinese Chinese Fortress marriages in Tangerang is referred to as the rites of passage when the bride and groom offer tea to an older person and the transition of the bride from the family as long as he or she will move to the family the groom and the procession section of the unmarried person will then marry. Communication rituals also show symbolic behavior that is child service to parents and expresses the deepest feelings of parents who have a final message specifically to the bride and groom.
\end{abstract}

Keywords: Communication, Ritual Communication, Tea Pay, Benteng Chinese Marriage, Tangerang.

\begin{abstract}
Abstrak
Cina Benteng merupakan komunitas terkenal karena dianggap masih melestarikan tradisi kebudayaan Tionghoa. Salah satu kebudayaanya adalah Teh Pai. Teh Pai diwariskan melalui proses komunikasi antar generasi. Dalam ritual Teh Pai terdapat proses komunikasi yang melibatkan perasaan terdalam antara pengantin dan orang yang lebih tua. Perasaan terdalam tersebut merupakan bagian dari komunikasi ritual. Tujuan penelitian ini adalah untuk mengetahui komunikasi ritual Teh Pai pada pernikahan Tionghoa Cina Benteng di Tangerang. Konsep yang digunakan dalam penelitian ini adalah komunikasi, komunikasi ritual dan budaya. Metode penelitian yang digunakan adalah metode penelitian kualitatif fenomenologi secara deskriptif. Data yang dianalisis diperoleh dari hasil wawancara mendalam dengan lima narasumber. Kesimpulan dari penelitian ini adalah komunikasi ritual yang terdapat dalam Teh Pai pada pernikahan Tionghoa Cina Benteng di Tangerang disebut sebagai rites of passage atau ritus peralihan saat kedua mempelai menyuguhkan teh kepada orang yang lebih tua dan peralihan mempelai perempuan dari keluarga asal kemudian ia akan berpindah ke keluarga mempelai laki-laki serta bagian prosesi dari orang yang belum menikah kemudian akan menikah. Komunikasi ritual juga menunjukkan perilaku simbolik yaitu bakti anak kepada orang tua dan menyatakan perasaan terdalam orang tua yang memiliki pesan terakhir khusus kepada kedua mempelai.
\end{abstract}

Kata Kunci: Komunikasi, Komunikasi Ritual, Teh Pai, Pernikahan Tionghoa Cina Benteng, Tangerang. 


\section{Pendahuluan}

Salah satu komunitas Tionghoa di Tangerang yang dianggap paling lama menetap adalah Cina Benteng. Menurut kitab sejarah Sunda yang berjudul Tina Layang Parahyang dalam buku yang berjudul Chiou Thau Pernikahan Adat Cina Benteng karya Kurniawan Halianto disebutkan bahwa masuknya leluhur orang Cina Benteng dimulai pada tahun 1407 Masehi. Kitab itu menceritakan tentang mendaratnya rombongan pertama dari dataran Cina yang dipimpin Tjen Tjie Lung alias Halung di muara Sungai Cisadane. Tanah di muara Sungai Cisadane diolah oleh Halung beserta teman-temannya menjadi tanah pertanian yang subur. Tanah ini terus berkembang dan akhirnya menjadi sebuah pelabuhan bernama Pangkalan Tang Lang. Pelabuhan ini sering dikunjungi pedagang Portugis, India, dan Cina. Oleh orang sekitar, daerah ini kemudian lebih dikenal dengan sebutan "Teluk Naga". Orang Tionghoa yang tinggal di Tangerang biasa menyebut diri mereka Tang Ren atau orangorang Tang. Sebutan Cina Benteng muncul karena disana dulunya terdapat sebuah benteng Makassar peninggalan kerajaan Banten yang digunakan untuk berlindung dari Belanda (Halianto, 2016).

Komunitas Cina Benteng terkenal karena dianggap masih melestarikan tradisi kebudayaan Tionghoa. Budaya menurut Shiraey dan Levy dalam buku Sarlito Wirawan Sarwono yang berjudul Psikologi Lintas Budaya merupakan suatu set dari sikap, perilaku, dan simbol-simbol yang dimiliki bersama oleh manusia dan biasanya dikomunikasikan dari satu generasi ke generasi berikutnya. Manusia tidak lahir dengan membawa budaya, melainkan budaya tersebut diwariskan dari generasi ke generasi (Sarwono, 2016).

Berbagai tradisi budaya yang dilakukan bukan hanya perayaan tradisional, melainkan juga tradisi pernikahan tradisional. Salah satu bagian terpenting dari pernikahan Tionghoa adalah Teh Pai. Teh Pai dalam buku yang berjudul Chiou Thau Pernikahan Adat Cina Benteng adalah salah satu ritual yang paling dikenal dan nyaris tidak pernah terlewatkan dalam setiap pernikahan Tionghoa Cina Benteng. Ritual Teh Pai ini merupakan ritual untuk menyajikan teh kepada orang tua dan kerabat pasangannya yang dituakan ataupun kerabat yang sudah menikah. Ritual Teh Pai berfungsi sebagai upacara atau tradisi perkenalan antar kedua belah pihak mempelai. Kedua mempelai akan bergantian menyajikan teh. Biasanya urutan menyuguhkan teh dimulai dari orang yang paling tua ke anggota keluarga yang paling muda (Halianto, 2016).

Dalam ritual Teh Pai terdapat proses komunikasi antara pengantin dengan orang yang lebih tua. Komunikasi menurut Richard West dan Lynn H. Turner dalam modul Pengantar Teori Komunikasi Analisis dan Aplikasi yang mengatakan komunikasi adalah proses sosial individu-individu yang menggunakan simbol-simbol untuk menciptakan dan mengintepretasikan makna dalam lingkungan individu tersebut (West dan Turner, 2008).

Komunikasi yang terjadi bukanlah komunikasi biasa seperti komunikasi seharihari melainkan komunikasi yang melibatkan perasaan terdalam antara pengantin dan orang yang lebih tua. Perasaan terdalam yang terjadi antara pengantin dan orang yang lebih tua dalam upacara Teh Pai pada pernikahan Tionghoa Cina Benteng tersebut merupakan bagian dari komunikasi ritual. Menurut Deddy Mulyana dalam buku Ilmu Komunikasi Suatu Pengantar, komunikasi ritual biasanya dilakukan secara kolektif. Sekelompok orang atau komunitas melakukan upacara-upacara berlainan sepanjang tahun dan sepanjang hidup, yang disebut para antropolog sebagai rites of passage. 
Dalam upacara itu orang mengucapkan kata-kata atau menampilkan perilaku-perilaku simbolik. Komunikasi ritual juga sering bersifat ekspresif, menyatakan perasaan terdalam seseorang (Mulyana, 2009).

Dalam penelitian ini, penulis tertarik untuk meneliti komunikasi ritual dalam upacara Teh Pai karena penulis ingin mengetahui komunikasi ritual Teh Pai pada pernikahan Tionghoa Cina Benteng di Tangerang. Alasan lainnya adalah karena penelitian mengenai komunikasi ritual Teh Pai pada pernikahan Tionghoa Cina Benteng di Tangerang belum pernah ada yang meneliti sebelumnya.

Rumusan masalah dalam penelitian ini adalah Bagaimana komunikasi ritual Teh Pai pada pernikahan Tionghoa Cina Benteng di Tangerang? Tujuan dalam penelitian ini adalah untuk mengetahui komunikasi ritual Teh Pai pada pernikahan Tionghoa Cina Benteng di Tangerang.

Teori yang dijadikan landasan dalam penelitian ini yaitu yang pertama komunikasi adalah proses sosial individu-individu yang menggunakan simbol-simbol untuk menciptakan dan mengintepretasikan makna dalam lingkungan individu tersebut (West dan Turner, 2008). Yang kedua komunikasi ritual adalah komunikasi yang dilakukan sekelompok orang dalam upacara berlainan sepanjang tahun sepanjang hidup yang disebut sebagai rites of passage atau ritus peralihan (Mulyana, 2009). Yang ketiga adalah budaya juga didefinisikan sebagai tatanan pengetahuan, pengalaman, kepercayaan, nilai, sikap, makna, waktu, peranan, hubungan ruang, objek-objek materi dan milik yang diperoleh sekelompok besar orang dari generasi ke generasi melalui usaha individu dan kelompok (Mulyana dan Rakhmat, 2005).

\section{Metode Penelitian}

Pada penelitian ini penulis menggunakan metode penelitian kualitatif secara deskriptif dengan pendekatan fenomenologi. Pendekatan kualitatif merupakan prosedur penelitian yang menghasilkan data deskriptif berupa kata-kata tertulis atau lisan dari orang-orang dan perilaku yang dapat diamati (Moleong, 2012). Penelitian fenomenologi selalu difokuskan pada menggali, memahami, dan menafsirkan arti fenomena, peristiwa, dan hubungannya dengan orang-orang biasa dalam situasi tertentu (Yusuf, 2014).

Penulis menggunakan penelitian kualitatif karena bertujuan untuk mengetahui bagaimana komunikasi ritual dalam upacara Teh Pai pada pernikahan Tionghoa Cina Benteng di Tangerang. Metode penelitian deskriptif kualitatif ini memungkinkan penulis untuk melakukan pengamatan secara mendalam tentang komunikasi ritual dalam upacara Teh Pai pada pernikahan Tionghoa Cina Benteng di Tangerang. Subjek dalam penelitian ini adalah Tionghoa Cina Benteng di Tangerang dan objek penelitian ini adalah komunikasi ritual Teh Pai. Metode pengumpulan data dilakukan dengan cara wawancara, observasi dan studi kepustakaan. Teknik analisis data dilakukan dengan pencarian dan pengaturan transkrip wawancara, observasi, mengikuti kegiatan dilapangan, serta dokumentasi beserta foto.

\section{Hasil Temuan dan Diskusi}

Berdasarkan hasil wawancara penulis dengan key informan dan informan, leluhur Tionghoa sejak zaman dahulu sudah mengenal Teh Pai. Teh Pai adalah suatu penghormatan dengan menyajikan teh kepada orang yang lebih tua. Pelaksanaan Teh Pai tidak bisa dilakukan disembarangan tempat. Ritual Teh Pai harus dilakukan di 
tempat persis di depan meja altar sembayang. Teh Pai selalu didahului oleh upacara sembayang atau ibadah kedua mempelai kepada Thien atau Yang Maha Kuasa dan para leluhur. Tujuannya agar upacara Teh Pai disaksikan oleh Thien atau Yang Maha Kuasa dan para leluhur. Jadi dalam konteks ini, dapat dilihat bahwa apapun yang dilakukan oleh seseorang atau keluarga yang masih hidup dilihat dan disaksikan oleh para leluhurnya. Ini sesuai dengan apa yang dikatakan Francis L.K. Hsu dalam bukunya yang berjudul Under The Ancestors' Shadow atau di bawah bayang-bayang leluhur. Hal ini yang disebut sebagai continuum atau keberlanjutan. Jadi keluarga itu berlanjut dan masih ada hubungan antara keluarga yang masih hidup dengan entitas atau bagian dari leluhur yang sudah meninggal. Artinya keluarga yang masih hidup tidak putus hubungan dengan para leluhur yang sudah meninggal. Untuk membentuk keluarga yang baru pun harus dilakukan di depan altar leluhur. Leluhur yang sudah meninggal diwujudkan dalam bentuk altar. Oleh karena itu Teh Pai tidak dilakukan di teras atau di kamar tetapi dilakukan persis di depan meja altar sembayangTeh Pai merupakan budaya yang sudah lama dikenal dan dilakukan Tionghoa Cina Benteng di Tangerang sejak 1407 Masehi. Leluhur Tionghoa Cina Benteng mewariskan budaya Teh Pai melalui komunikasi dengan memberikan petuah secara langsung kepada generasi muda dikeluarganya mengenai arti penting upacara Teh Pai.

Pada saat Teh Pai terdapat komunikasi ritual. Penjelasan komunikasi ritual berdasarkan hasil wawancara dengan key informan yang telah meneliti tentang budaya Tionghoa Cina Benteng selama sembilan tahun. Ia menjelaskan bahwa Teh Pai pada pernikahan Tionghoa Cina Benteng memiliki komunikasi ritual. Komunikasi ritual dalam Teh Pai memiliki arti mendalam bagi kedua mempelai dan orang yang lebih tua pada saat Teh Pai. Ia menjabarkan tentang komunikasi ritual dalam Teh Pai dapat terlihat sebagai rites of passage atau ritus peralihan. Penjabaran itu dimulai dari daur hidup atau life cycle orang Tionghoa sama seperti budaya lainnya yang memiliki perayaan kelahiran, pernikahan dan kematian. Dalam daur hidup orang tionghoa, perayaan paling besar adalah perayaan pernikahan. Dalam perayaan pernikahan, dapat terlihat dua keluarga akan disatukan. Dalam tradisi pernikahan tradisonal Tionghoa yang patrilineal, nanti calon pengantin perempuan akan keluar dari keluarga asalnya sendiri untuk kemudian pindah menjadi keluarga besar suaminya. Dalam fenomena Teh Pai ini, keluarga mempelai perempuan mengantar dan melepaskan calon mempelai perempuan yang kemudian ia akan menjadi bagian dari keluarga besar mempelai laki-laki. Pada saat Teh Pai ini merupakan kesempatan bagi mempelai perempuan untuk menunjukkan hidangan teh terakhir kepada orang tua sebagai ungkapan terima kasih. Ketika Teh Pai kepada orang tua mempelai laki-laki, mempelai perempuan menunjukkan teh kepada orang tua mempelai laki-laki sebagai ungkapan ia akan berbakti kepada kedua orang tua dan keluarga besar mempelai laki-laki. Dalam posisi seperti ini yang disebut sebagai rites of passage atau ritus peralihan terutama bagi mempelai perempuan ada dua. Pertama, peralihan mempelai perempuan dari keluarga asal kemudian ia akan berpindah ke keluarga mempelai laki-laki yang akan menjadi suaminya. Kedua, rites of passage dalam Teh Pai diartikan sebagai satu bagian rangkaian prosesi dari orang yang belum menikah dan kemudian nanti akan menikah. Ia juga menjabarkan perilaku simbolik dan perasaan terdalam pengantin dengan orang yang lebih tua terlihat pada Teh Pai Tionghoa Cina Benteng. Perilaku simbolik tersebut telihat ketika orang tua terutama ibu mempelai perempuan akan memberikan pesan terakhir kepada anak perempuannya. Salah satu pesannya adalah anak perempuannya harus berbakti kepada keluarga suaminya sebagai keluarganya yang baru, jangan mempermalukan dan harus menjaga nama baik keluarga asal anak 
Putri Dewiyanto, Suzy S. Azeharie: Studi Komunikasi Ritual Teh Pai Pada Pernikahan Tionghoa Cina Benteng di Tangerang

perempuan di depan keluarga besar mempelai laki-laki yang akan menjadi suaminya. Pada saat Teh Pai juga terlihat perasaan terdalam antara kedua mempelai dengan orang tua sangat ekspresif. Misalnya kedua mempelai akan sedih terharu, terutama bagi mempelai perempuan yang akan meninggalkan keluarga asalnya.

Sampai saat ini Teh Pai masih dijalankan oleh generasi penerus Tionghoa seperti yang dilakukan oleh Ayu Susanti dan Erih Chandra. Erih Chandra dan Ayu Susanti sebagai keturunan Tionghoa Cina Benteng melakukan ritual Teh Pai dalam upacara pernikahannya pada Sabtu 28 September 2018 pukul 05.00 dini hari di Rumah Kawin 9 Saudara, Tangerang. Penentuan waktu pelaksanaan Teh Pai ini merupakan hasil konsultasi pihak keluarga dengan seorang suhu yang secara professional yang biasa dimintai bantuan untuk menghitung hari baik. Penulis mengamati secara langsung ritual Teh Pai yang dilakukan oleh Erih Chandra dan Ayu Susanti dalam upacara pernikahannya. Ritual Teh Pai dilakukan oleh Erih Chandra dan Ayu Susanti sebagai calon pengantin. Ritual Teh Pai dilaksanakan setelah melakukan beberapa bagian upacara adat pernikahan Tionghoa Cina Benteng seperti upacara Chio Tao, sembayang kepada Thien atau Yang Maha Kuasa dan lainnya. Ritual Teh Pai ini dipandu oleh seorang penata rias pernikahan adat Tionghoa Cina Benteng dan diiringi musik tradisional Cina Benteng. Pelaksanaan ritual Teh Pai dilakukan satu persatu mempelai kepada masing-masing keluarga kedua mempelai.

Gambar 1. Ayu Susanti Melakukan Teh Pai Kepada Ibu dan Wakil Bapak Dari Pihak Mempelai Laki-Laki

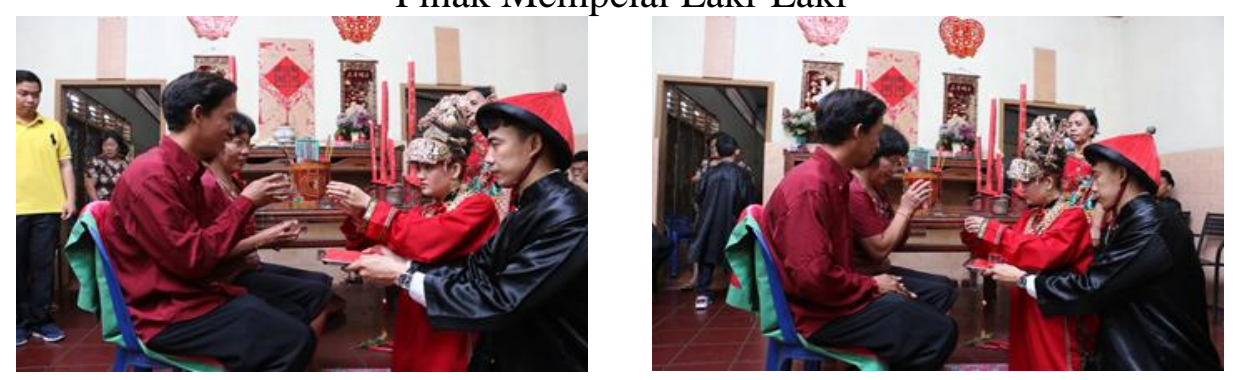

Sumber: Dokumentasi Penulis (2018)

Gambar 2. Erih Chandra Melakukan Teh Pai Kepada Nenek Sebagai Wakil Ibu dan Bapak Dari Pihak Mempelai Perempuan
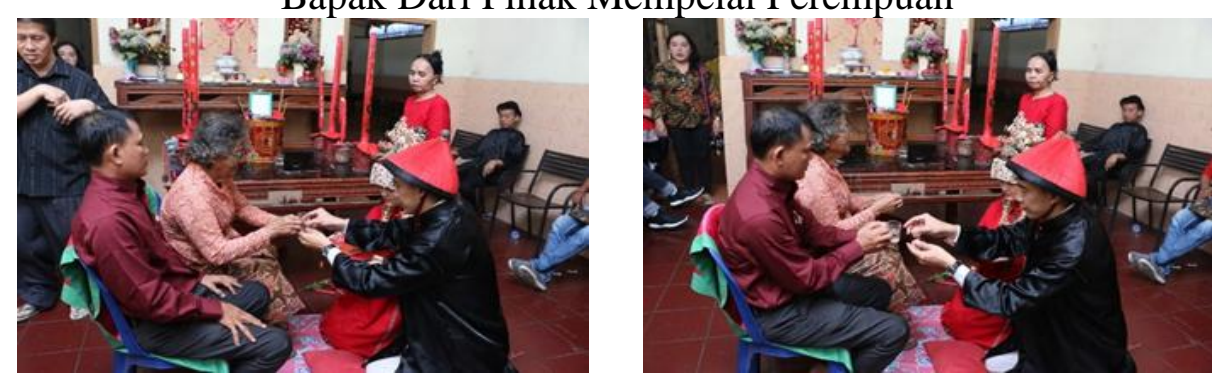

Sumber: Dokumentasi Penulis (2018)

Saat Teh Pai, Erih Chandra dan Ayu Susanti masih menggunakan pakaian adat pernikahan Cina Benteng. Kedua orang tua mempelai tidak menggunakan pakaian adat, tetapi menggunakan pakaian bebas dan rapih. Kedua mempelai melakukan Teh Pai di sebuah ruangan persis di depan meja altar sembayang. Karena sebelum melakukan Teh Pai, kedua mempelai sembayang terlebih dahulu kepada Thien atau Yang Maha Kuasa dan kepada para leluhur. 
Teh Pai yang dilakukan Erih Chandra dan Ayu Susanti merupakan budaya yang sudah lama dikenal dan dilakukan Tionghoa Cina Benteng di Tangerang sejak 1407 Masehi. Menurut Ann Wan Seng dalam buku Adat dan Pantang Larang Orang Cina mengungkapkan upacara minum teh sangat penting karena dengan berbuat demikian, perasaan menghormati orang tua dikekalkan walaupun sudah berumah tangga. Menyembah orang yang lebih tua juga sebagai tanda berterima kasih di atas penjagaan dan perlindungan yang diberikan kepada pengantin perempuan (Seng, 1994). Salah satu ritual yang paling dikenal dan nyaris tidak pernah terlewatkan dalam setiap pernikahan Tionghoa Cina Benteng menurut Kurniawan Halianto dalam buku yang berjudul Chiou Thau Pernikahan Adat Cina Benteng adalah menyajikan teh atau Teh Pai. Ritual Teh Pai ini merupakan ritual untuk menyajikan teh kepada orang tua dan kerabat pasangannya yang dituakan ataupun kerabat yang sudah menikah. Ritual Teh Pai berfungsi sebagai upacara atau tradisi perkenalan antar kedua belah pihak mempelai. Kedua mempelai akan bergantian menyajikan teh. Biasanya urutan menuyuguhkan teh dimulai dari orang yang paling tua ke anggota keluarga yang paling muda (Halianto, 2016).

Berdasarkan analisa penulis Teh Pai adalah ritual menyajikan teh kepada keluarga yang lebih tua. Teh Pai sebagai ungkapan bakti kepada keluarga pengantin laki-laki dan ungkapan terima kasih kepada keluarga pengantin perempuan. Ritual Teh Pai ini merupakan tradisi turun temurun yang terus dijalankan oleh orang Tionghoa Cina Benteng.

Budaya menurut Deddy Mulyana dan Jalaluddin Rakhmat dalam buku yang berjudul Komunikasi Antarbudaya berkenaan dengan cara hidup. Manusia belajar berpikir, merasa, mempercayai dan mengusahakan apa yang patut menurut budayanya. Budaya juga didefinisikan sebagai tatanan pengetahuan, pengalaman, kepercayaan, nilai, sikap, makna, waktu, peranan, hubungan ruang, objek-objek materi dan milik yang diperoleh sekelompok besar orang dari generasi ke generasi melalui usaha individu dan kelompok. Budaya juga berkenaan dengan sifat dari objek-objek materi yang memainkan peranan penting dalam kehidupan sehari-hari (Mulyana dan Rakhmat, 2005).

Berdasarkan analisa penulis bahwa budaya merupakan pengetahuan dan nilainilai yang dimiliki dan dikomunikasikan ke generasi berikutnya. Upacara Teh Pai sebagai tradisi bagi masyarakat Tionghoa Cina Benteng merupakan budaya yang diwariskan secara turun termurun.

Menurut kitab sejarah Sunda yang berjudul Tina Layang Parahyang dalam buku yang berjudul Chiou Thau Pernikahan Adat Cina Benteng karya Kurniawan Halianto menyebutkan bahwa masuknya leluhur orang Cina Benteng dimulai pada tahun 1407 Masehi (Halianto, 2016). Sementara Ching dalam buku Etnis Cina Perantauan di Aceh karya A. Rani Usman mengatakan bahwa orang Tionghoa terikat dengan ideologi dan kebudayaan masa lampau serta taat pada ajaran Konfusian. Salah satu ajaran Konfusian adalah kepercayaan yang kuat mengenai hubungan antara masa lampau dan masa kini. Orang Tionghoa sangat menjunjung tinggi masa lampau dan nenek moyang atau leluhurnya serta cinta kebudayaan masa lampau. Masa lampau merupakan cerminan keberhasilan masa kini (Usman, 2009). Menurut Chu Tung - Shu dalam buku yang berjudul Law and Society in Traditional China mengatakan leluhur menempati tempat utama dan berperan penting dalam tata pernikahan. Pernikahan menjadi urusan keluarga, bukan urusan individu (Shu, 1965). Masih dalam buku yang sama dijelaskan sebuah perkawinan itu harus disetujui oleh kakek atau orang tua. 
Putri Dewiyanto, Suzy S. Azeharie: Studi Komunikasi Ritual Teh Pai Pada Pernikahan Tionghoa Cina Benteng di Tangerang

Kalau mereka sudah meninggal, maka yang memegang peran adalah saudara tertua (Shu, 1965).

Berdasarkan analisa penulis bahwa keberadaan orang Tionghoa Cina Benteng di Tangerang sudah lama sejak 1407 Masehi. Kedatangan orang Tionghoa Cina Benteng di Tangerang membawa tradisi dan kepercayaan konfusian dari negeri asal sekaligus melakukan kegiatan perdagangannya. Salah satu yang dibawa adalah upacara Teh Pai yang menjadi bagian dari warisan yang turun temurun.

Dalam ritual Teh Pai tersebut terdapat proses komunikasi antara Erih Chandra dan Ayu Susanti sebagai pengantin dengan orang yang lebih tua. Menurut Richard West dan Lynn H. Turner dalam modul Pengantar Teori Komunikasi Analisis dan Aplikasi yang mengatakan komunikasi adalah proses sosial individu-individu yang menggunakan simbol-simbol untuk menciptakan dan mengintepretasikan makna dalam lingkungan individu tersebut (West dan Turner, 2008). Berdasarkan analisa penulis bahwa komunikasi sebagai proses sosial individu yang menggunakan simbolsimbol untuk menciptakan dan mengintepretasikan makna dalam berkomunikasi yang dilakukan terlihat dalam upacara Teh Pai yang masih dilakukan oleh Ayu Susanti dan Erih Chandra. Mereka masih melaksanakan upacara Teh Pai berdasarkan komunikasi langsung dari orang tua.

Komunikasi yang terjadi bukanlah komunikasi biasa seperti komunikasi seharihari melainkan komunikasi yang melibatkan perasaan terdalam antara pengantin dan orang yang lebih tua. Perasaan terdalam yang terjadi antara Erih Chandra dan Ayu Susanti sebagai pengantin dan orang yang lebih tua dalam upacara Teh Pai pada pernikahannya merupakan bagian dari komunikasi ritual. Menurut Deddy Mulyana dalam buku Ilmu Komunikasi Suatu Pengantar, komunikasi ritual biasanya dilakukan secara kolektif. Sekelompok orang atau komunitas melakukan upacara-upacara berlainan sepanjang tahun dan sepanjang hidup, yang disebut para antropolog sebagai rites of passage. Dalam upacara itu orang mengucapkan kata-kata atau menampilkan perilaku-perilaku simbolik. Komunikasi ritual juga sering bersifat ekspresif, menyatakan perasaan terdalam seseorang (Mulyana, 2009).

Berdasarkan analisa dan hasil pengamatan langsung penulis saat upacara pernikahan Erih Chandra dan Ayu Susanti bahwa hasil wawancara dan teori komunikasi ritual yang terdapat dalam Teh Pai sesuai dengan Teh Pai yang telah dilakukan oleh Erih Chandra dan Ayu Susanti. Ritual Teh Pai Erih Chandra dan Ayu Susanti yang menunjukkan rites of passage atau ritus peralihan saat mereka melakukan Teh Pai dengan menyuguhkan teh kepada orang yang lebih tua dan peralihan mempelai perempuan dari keluarga asal kemudian ia akan berpindah ke keluarga mempelai lakilaki serta bagian prosesi dari orang yang belum menikah kemudian akan menikah. Komunikasi ritual juga menunjukkan perilaku simbolik yaitu bakti anak kepada orang tua dan menyatakan perasaan terdalam orang tua yang memiliki pesan terakhir khusus kepada kedua mempelai.

\section{Simpulan}

Leluhur Tionghoa sejak zaman dahulu sudah mengenal Teh Pai. Teh Pai merupakan budaya yang sudah lama dikenal dan dilakukan Tionghoa Cina Benteng di Tangerang sejak 1407 Masehi. Mereka mewariskan budaya Teh Pai melalui komunikasi dengan memberikan petuah secara langsung kepada generasi muda dikeluarganya mengenai arti penting upacara Teh Pai. Hal tersebut terlihat jelas pada ritual Teh Pai yang masih dilakukan oleh Erih Chandra dan Ayu susanti berdasarkan 
komunikasi langsung dari orang tuanya. Teh Pai adalah suatu penghormatan dengan menyajikan teh kepada orang yang lebih tua. Pada saat Teh Pai terdapat komunikasi ritual yang memiliki arti mendalam bagi kedua mempelai dan orang yang lebih tua. Komunikasi ritual yang terdapat dalam Teh Pai pada pernikahan Tionghoa Cina Benteng yang menunjukkan rites of passage atau ritus peralihan adalah saat mereka melakukan Teh Pai dengan menyuguhkan teh kepada orang yang lebih tua. Penyuguhan teh kepada orang yang lebih tua bukan semata-mata hanya minum teh, tetapi menunjukkan perilaku simbolik yaitu bakti anak kepada orang yang lebih tua, terutama kepada orang tua. Komunikasi ritual dalam Teh Pai tersebut juga menyatakan perasaan terdalam antara mereka dan orang yang lebih tua, terutama ketika orang tua mempelai memberikan pesan kepada mereka untuk memberikan perasaan bahagia dan jangan ada pikiran buruk.

\section{Ucapan Terima Kasih}

Penulis mengucapkan terima kasih kepada dosen pembimbing skripsi Bu Suzy S. Azeharie, key informan, Informan dan seluruh pihak yang telah membantu selama proses penelitian ini berlangsung sampai dengan pembuatan artikel jurnal ini.

\section{Daftar Pustaka}

Azeharie, Suzy. (2015). Pola Komunikasi Antara Pedagang dan Pembeli di Desa Pare, Kampung Inggris Kediri. Jurnal Komunikasi. 7(2).

Halianto, Kurniawan. (2016). Chiou Thau Pernikahan Adat Cina Benteng. Jakarta: Gramedia Pustaka Utama.

Moleong, Lexy J. (2012). Metodologi Penelitian Kualitatif. Bandung: Remaja Rosdakarya.

Mulyana, D., \& Jalaluddin Rakhmat. (2005). Komunikasi Antarbudaya. Bandung: Remaja Rosdakarya.

Mulyana, Deddy. (2009). Ilmu Komunikasi Suatu Pengantar. Bandung: Remaja Rosdakarya.

Sarwono, Sarlito Wirawan. (2016). Psikologi Lintas Budaya. Jakarta: PT. Raja Grafindo Persada.

West, R., \& Lynn H. Turner. (2008). Pengantar Teori Komunikasi Analisis dan Aplikasi (Edisi ke-3). Jakarta: Salemba Humanika. 